\title{
LATIHAN GABUNGAN PENYELAMATAN DIRI DARI BENCANA BANJIR KERJASAMA PRODI NERS, BPBD, PPNI DAN KARANG TARUNA KELURAHAN BENTIRING
}

DOI: https://doi.org/10.33024/jkpm.v4i5.5258

\author{
Fernalia $^{1^{*}}$, Pawiliyah ${ }^{2}$, Vice Elese ${ }^{3}$, Saleh $^{4}$, Dedi Haryanto ${ }^{5}$, Tarzani $^{6}$, Ichsan \\ Dwi Putra \\ 1,2,6,7STIKES Tri Mandiri Sakti \\ ${ }^{3} \mathrm{PMI}$ Provinsi Bengkulu \\ ${ }^{4}$ DPW PPNI Provinsi Bengkulu \\ ${ }^{5}$ UPTD Puskesmas Muara Bangkahulu
}

Disubmit: 01 Oktober 2021 Diterima: 03 Oktober 2021 Diterbitkan: 05 Oktober 2021

Email korespondensi: lia_fernalia@yahoo.com

\begin{abstract}
ABSTRAK
Banjir merupakan luapan air yang melebihi tinggi muka air normal sehingga meluap dari palung sungai yang menyebabkan terjadinya genangan air dilahan rendah. Pada umumnya banjir terjadi karena curah hujan yang tinggi yang mengakibatkan sistem pengaliran air yang terdiri dari sungai dan anak sungai serta sistem saluran drainase dan kanal penampung banjir buatan yang ada tidak mampu menampung akumulasi air hujan sehingga meluap (Mandasari, 2020). Banjir merupakan bencana alam yang ketiga terbesar didunia yang telah banyak menelan korban jiwa dan kerugian harta benda. Angka kejadian banjir bandang di Bengkulu menuruti peringkat ke 7 secara nasional dengan 28 kali kejadian banjir bandang dan 231 kejadian banjir, sedangkan kejadian banjir dan tanah longsor di provinsi Bengkulu telah melanda 9 kabupaten dan kota dengan dampak akibat banjir terdapat 30 jiwa meninggal, 6 jiwa hilang, 4 jiwa lukaluka, 12.000 mengungsi dan 13.000 terdampak akibat banjir. Tujuan pengabdian masyarakat ini adalah meningkatkan keterampilan kelompok karang taruna dalam melakukan penyelamatan diri dari bencana banjir sehingga dapat mengurangi angka kerugian dan kematian saat terjadi banjir di kelurahan bentiring Kota Bengkulu. Terdapat perubahan keterampilan tentang cara penyelamatan diri dari bencana banjir, dengan demikian latihan gabungan penyelamatan diri dari bencana banjir pada kelompok karang taruna di kelurahan bentiring Kota Bengkulu sangat efektif untuk meningkatkan keterampilan kelompok karang taruna dalam melakukan penyelamatan diri agar dapat mengurangi angka kerugian dan kematian saat terjadi banjir. Diharapkan dengan melakukan latihan gabungan penyelamatan diri, masyarakat menjadi lebih siap saat terjadi banjir.
\end{abstract}

Kata Kunci: Latihan Gabungan, penyelamatan diri, banjir. 


\begin{abstract}
Flooding occurs when the regular water level of a river exceeds the capacity of the riverbed, causing pools on low terrain. Floods are caused by excessive rainfall, which causes a water drainage system comprised of rivers and tributaries, as well as drainage systems and artificial flood storage canals, to become unable to accept the buildup of rainwater, causing it to overflow. (Mandasari, 2020). Floods are the world's third-largest natural disaster, claiming many lives and causing significant property damage. Bengkulu ranks 7 th in the country for flash floods, with 28 flash floods and 231 floods while floods and landslides have impacted 9 districts and cities in Bengkulu province. 30 people died in floods, 6 people went missing, 4 people were injured, 12,000 people were displaced, and 13,000 people were affected (BNPB Bengkulu Province, 2019). The purpose of this community service project is to develop the skills of young groups in self-rescue from flood disasters so that they can reduce the number of losses and deaths in Bentiring Village, Bengkulu City, when floods come. The combined exercise to save themselves from flood disasters in youth groups in Bentiring village, Bengkulu City, has been highly beneficial in developing the skills of youth groups in carrying out self-rescue in order to limit the amount of losses and deaths when floods come. The community will be better prepared in the case of a flood if they practice collaborative self-rescue exercises.
\end{abstract}

Keywords: combined exercise, self-rescue, flood.

\title{
1. PENDAHULUAN
}

Banjir merupakan luapan air yang melebihi tinggi muka air normal sehingga meluap dari palung sungai yang menyebabkan terjadinya genangan air dilahan rendah. Pada umumnya banjir terjadi karena curah hujan yang tinggi yang mengakibatkan sistem pengaliran air yang terdiri dari sungai dan anak sungai serta sistem saluran drainase dan kanal penampung banjir buatan yang ada tidak mampu menampung akumulasi air hujan sehingga meluap (Mandasari, 2020). Banjir merupakan bencana alam yang perlu mendapat perhatian, karena mengancam jiwa dan ekonomi masyarakat dan merupakan bencana alam yang ke tiga terbesar di dunia yang telah banyak menelan korban jiwa dan kerugian harta benda. Begitu juga fenomena yang terjadi di Indonesia, berdasarkan data dari Badan Nasional Penanggulangan Bencana (BNPB) yang menunjukan bahwa pada tahun 2016 bencana yang terjadi di Indonesia terbanyak adalah bencana hidrometeorologi yang didominasi oleh banjir, longsor, dan puting beliung (Akhirianto, 2018).

Badan Nasional Penanggulangan Bencana (BNPB) mencatat sepanjang tahun 2019 telah terjadi 3.814 kejadian dengan 784 di antaranya merupakan bencana banjir (BNPB, 2020). Banjir terjadi hampir di sebagian besar wilayah Indonesia. Bahkan beberapa wilayah yang dulunya bukan merupakan kawasan rawan banjir, di tahun 2019 mengalami banjir besar, seperti yang terjadi di Provinsi Bengkulu, banjir melanda di sembilan kabupaten/kota. Angka kejadian banjir bandang di Bengkulu menuruti peringkat ke 7 secara nasional dengan 28 kali kejadian banjir bandang dan 231 kejadian banjir (Badan Pusat Statistik Indonesia, 2018), sedangkan kejadian banjir dan tanah longsor di provinsi Bengkulu telah melanda 9 kabupaten dan kota dengan dampak akibat banjir terdapat 30 jiwa 
meninggal, 6 jiwa hilang, 4 jiwa luka-luka, 12.000 mengungsi dan 13.000 terdampak akibat banjir (BNPB Provinsi Bengkulu, 2019). Data BNPB menyebutkan bahwa bencana banjir tersebut telah mengakibatkan 30 orang meninggal dunia, 12.000 warga harus mengungsi, 6 orang dinyatakan hilang, 4 orang luka-luka, 13.000 jiwa terdampak, 1.225 rumah rusak, 1.187 unit rumah terendam, 7 fasilitas pendidikan rusak ringan, 7 fasilitas pendidikan terendam lumpur, 40 titik infrastruktur terendam, 9 unit sarpras perikanan dan kelautan rusak, 3.000 hektar sawah dan kebun rusak, dan 857 hewan ternak mati (BNPB, 2019).

Aktivitas manusia berperan besar bagi terjadinya bencana banjir. Seperti bencana banjir dan tanah longsor yang terjadi di Bengkulu. Menurut Kepala Pusat Data dan Informasi dan Humas BNPB, banjir di Bengkulu disebabkan oleh adanya kerusakan lingkungan di daerah hulu akibat aktivitas pertambangan, perkebunan, dan pembangunan pemukiman. Alih fungsi lahan kawasan hulu dari hutan menjadi perkebunan, kawasan tambang, dan pemukiman menjadi faktor penyebab terjadinya banjir di Bengkulu, selain curah hujan yang ekstrim (Ronald, 2019).

Hasil rekapitulasi data bencana tahun 2019 dari BNPB Kota Bengkulu terdapat 371 rumah dan $1.484 \mathrm{KK}$ yang terkena dampak bencana banjir pada tanggal 26-29 April 2019 yang disebabkan oleh hujan deras dan aliran sungai naik sehingga menyebabkan banjir di Kelurahan Bentiring Kota Bengkulu.

\section{MASALAH}

Alasan tim melakukan latihan gabungan tentang cara penyelamatan diri dari bencana banjir adalah wilayah Bentiring merupakan wilayah yang selalu mengalami banjir dengan atau tanpa curah hujan tinggi hal ini disebabkan karena Bentiring merupakan wilayah yang dikelilingi oleh aliran sungai dan memiliki letak geografis lebih rendah dibanding wilayah sekitarnya. Bentiring juga merupakan wilayah yang selalu mengalami kerugian akibat bencana banjr baik kerugian dalam bidang infrastruktur, pertanian, peternakan, kesehatan dan bahkan hingga kematian. Hal ini menjadi dasar tim untuk melakukan sosialisasi.

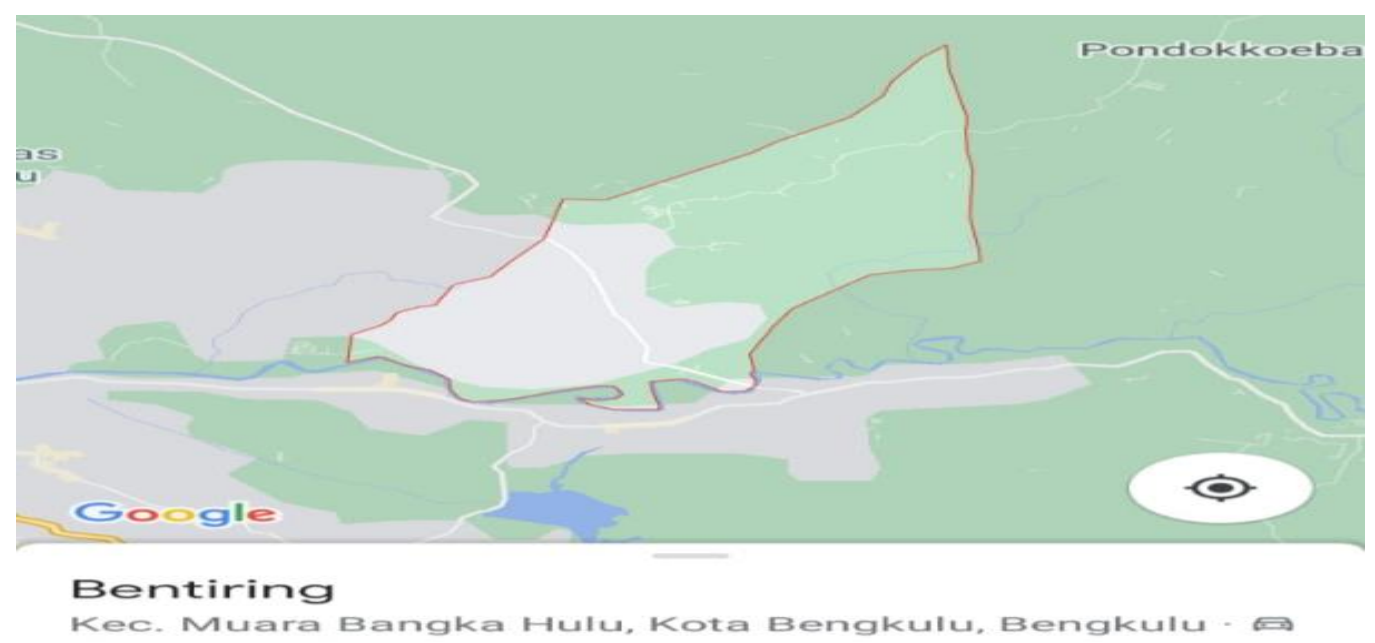

Gambar 1: Lokasi Pengabdian Masyarakat 


\section{METODE}

1. Tujuan Persiapan

Tahap persiapan dari kegiatan adalah survey lokasi,pengurusan perizinan ke BPBD, Koordinasi Ke Kelurahan Bentiring, koordinasi ke lokasi latihan gabungan, menyiapkan pre planing, penentuan jadwal latihan gabungan, latihan gabungan dilakukan 16 sampai 20 september 2021.

2. Tahap pelaksanan

Dilakukan dengan memberikan teknik-teknik dalam penyelamatan diri saat terjadi banjir kepada kelompok karang taruna kelurahan bentiring Kota Bengkulu.

a. Evaluasi

i. Struktur

Peserta adalah kelompok karang taruna yang berada di Kelurahan Bentiring kota Bengkulu. Media dan Tempat pelaksanaan sudah sesuai dengan rencana yang dibuat dan perlengkapan yang dilakukan untuk Peran pelaksana sudah sesuai dengan tugas yang telah ditetapkan.

ii. Proses

Pelaksanaan kegiatan dilakukan pada 16 sampai 20 September 2021 pukul $08.00 \mathrm{~S} / \mathrm{d} 12.00$ wib sesuai dengan jadwal iii. Hasil yang telah di rancanakan.

Untuk meningkatkan kemampuan masyarakat dalam melalukan penyelamatan diri saat bencana banjir melanda dengan tujuan menghindari dan mengurangi risiko kesakitan dan kematian akibat bencana banjir.

\section{HASIL DAN PEMBAHASAN}

Metode pelaksanan dalam kegiatan ini adalah melakukan latihan gabungan penyelamatan diri dari bencana banjir serta mengembangkan budaya sadar bencana banjir yang dilaksanakan pada tanggal 16 sampai 20 September 2021. Pelaksanaan latihan gabungan ditunjukan untuk kelompok warga di Kelurahan Bentiring kota Bengkulu yang diharapakn untuk menyebarkan informasi yang didapat kesetiap warga setempat. Media dan alat yang di gunakan berupa alat pelampung, perahu, pompa, Repair kit, Dry , sound sistem, bahan sosialisasi, video yang digunakan adalah ceramah, diskusi serta penayangan video. Berikut dokumentasi pelaksanaan sosialisasi cara penyelamatan diri dari bencana banjir pada Kelompok karang taruna Kelurahan Bentiring Kota Bengkulu.
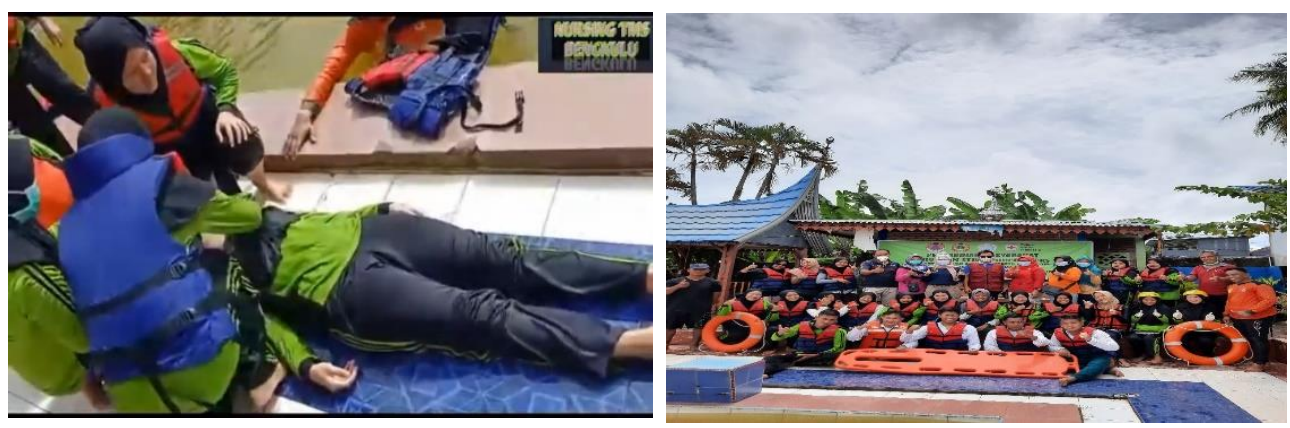

Gambar 4.1 pelaksanaan kegaiatan pengabdian 


\section{KESIMPULAN}

Berdasarkan hasil kegiatan pengabdian masyarakat mengenai latihan gabungan penyelamatan diri dari bencana banjir bersama prodi keperawatan, BPBD, PPNI, dan karang taruna kelurahan bentiring kota Bengkulu, maka dapat di simpulkan bahwa latihan gabungan berpengaruh terhadap peningkatan pengetahuan masyarakat tentang cara menyelamatkan diri saat bencana banjir datang.

\section{DAFTAR PUSTAKA}

Akhirianto, A. N. (2018). Pengetahuan dan Kesiapsiagaan Masyarakat terhadap Bencana Banjir di Kota Bekasi. Jurnal Alami, Vol 2, No.1, hal. 63-64.

BNPB. (2012). Peraturan Kepala Badan Nasional Penaggulangan Bencana Nomor 7 Tahun 2012 Tentang Pedoman Pengelolaan Data dan Informasi Bencana Indonesia, http://www.bnpb.go.id/pengetahuan-bencana/definisidanjenis-bencana, diakses tanggal 3 Oktober 2016

BNPB. (2019). Banjir dan Tanah Longsor Provinsi Bengkulu. https://bnpb.go.id/infografis/infografis-bencana-banjir-dan-longsorbengkulu

Badan Pusat Statistik. (2018). Banyaknya Desa/Kelurahan Menurut Jenis Bencana Alam dalam Tiga Tahun Terakhir (Desa). https: //www.bps.go.id/indicator/168/954/1. Diakses Januari 2021

Mandasari, N., \& Ip, S. (2020). Penanggulangan Bencana Banjir Di Sungai Batang Merao Pada Badan Penanggulangan Bencana Daerah Kota Sungai Penuh. Jurnal Administrasi Nusantara, 3(2), 43-51.

BNPB. (2020). Data Informasi Bencana Indonesia. Retrieved from http://bnpb.cloud/dibi/ , on April 28, 2020.

Ronald. (2019). Faktor-Faktor Terjadinya Banjir Bengkulu yang Tewaskan 29 Orang.

https: / / www.liputan6.com/news/read/3954170/faktor-faktorterjadinyabanjir-bengkulu-yang-tewaskan-29-orang, on May 29, 2020. 